\title{
Molecular Assessment of Kidney Allografts: Are We Closer to a Daily Routine?
}

\author{
Andriy TRAILIN ${ }^{1}$, Petra HRUBA ${ }^{1}$, Ondrej VIKLICKY ${ }^{1,2}$ \\ ${ }^{1}$ Transplant Laboratory, Institute for Clinical and Experimental Medicine, Prague, Czech Republic, \\ ${ }^{2}$ Department of Nephrology, Transplant Centre, Institute for Clinical and Experimental Medicine, \\ Prague, Czech Republic
}

Received August 9, 2019

Accepted December 3, 2020

Epub Ahead of Print March 23, 2020

\begin{abstract}
Summary
Kidney allograft pathology assessment has been traditionally based on clinical and histological criteria. Despite improvements in Banff histological classification, the diagnostics in particular cases is problematic reflecting a complex pathogenesis of graft injuries. With the advent of molecular techniques, polymerasechain reaction, oligo- and microarray technologies allowed to study molecular phenotypes of graft injuries, especially acute and chronic rejections. Moreover, development of the molecular microscope diagnostic system (MMDx) to assess kidney graft biopsies represents the first clinical application of a microarraybased method in transplantation. Whether MMDx may replace conventional pathology is the subject of ongoing research, however this platform is particularly useful in complex histological findings and may help clinicians to guide the therapy.
\end{abstract}

\section{Key words}

Kidney transplantation • Gene expression • RT-qPCR • Microarray - MMDx • Molecular microscope

\section{Corresponding author}

Ondrej Viklicky, Department of Nephrology, Transplant Centre, Institute for Clinical and Experimental Medicine, Videnska 1958/9, 14021 Prague, Czech Republic. E-mail: onvi@ikem.cz

\section{Introduction}

Kidney transplantation is the treatment of choice for end-stage renal disease. Acute and chronic rejection represent the main obstacle for long-term outcomes
(Sellares et al. 2012, Sis et al. 2010). Kidney graft rejection diagnostics was traditionally based on clinical and histological criteria. The Banff classification was introduced to improve and standardise histological diagnostics for transplanted organs (Solez et al. 1993). However, histology is descriptive in principle and limited to semi-quantitative assessment only. Therefore, similar morphologies may actually reflect non-homogenous cohorts with different outcomes. A better understanding of the mechanisms behind kidney graft rejection could yield novel preventive, diagnostic, and therapeutic approaches. Transcriptomics is an innovative tool used in several medical disciplines, including transplantation (Halloran et al. 2014). Assessment of molecular disturbances has already been incorporated into the Banff classification of kidney allograft pathology (Haas et al. 2014, Loupy et al. 2017, Haas et al. 2018). This review summarises the updated developments on molecular pathology in kidney transplantation.

\section{Limitations of traditional diagnostic tools}

Kidney grafts can be affected by nephrotoxicity, infections, vascular pathology, as well as transmitted, recurrent, or de novo diseases, among which the rejection is the most important. Two types of kidney allograft rejection have been recognized, T-cell-mediated (TCMR) and antibody-mediated rejection (ABMR). TCMR and ABMR differ in terms of pathogenesis, pathology, and prognosis, require tailored treatment, and cannot be 
distinguished exclusively based on clinical data ( $\mathrm{Sa}$ et al. 2016). Recently, as the main cause of kidney allograft loss in the long-term follow-up the ABMR has been considered (Sellares et al. 2012, Sis et al. 2010).

Histologically, TCMR is distinguished from ABMR by the presence of mononuclear tubulitis and interstitial inflammation while microvascular inflammation, arteritis, acute tubular injury or thrombotic microangiopathy are observed in the latter case (Cornell 2016, Haas et al. 2018). The presence of complement component $\mathrm{C} 4 \mathrm{~d}$ in the peritubular capillaries reflects antibody-endothelium interaction (Cornell 2016, Haas et al. 2018) in ABMR. However, C4d assay has poor reproducibility (Mengel et al. 2013). C4d staining results may vary from negative (which does not exclude ABMR), to diffuse positive, and depend on method used (Cornell 2016, Haas et al. 2014, Sis et al. 2010). Arteritis and glomerulitis may occur in both ABMR and TCMR (Cornell 2016), or may not be associated with rejection (Cornell 2016). Tubulitis with interstitial inflammation can be a feature of tubulointerstitial nephritis regardless of aetiology. Despite TCMR, tubulointerstitial inflammation may be borderline, although in other patients borderline changes can be benign (Hruba et al. 2015). Similarly, double contours are not entirely unique to transplant glomerulopathy (TG) in chronic ABMR, as they also occur in chronic thrombotic microangiopathy and recurrent or de novo immune complex glomerulonephritis (Cornell 2016). Furthermore, kidney grafts can undergo mixed rejection or a combination of several pathologies, especially at a late post-transplant stage.

Histology assessment is greatly influenced by sample size. On the issue of sampling error, the Banff community recommends the examination of two cores containing the renal allograft cortex (Racusen et al. 1999). Histological lesions are graded semi-quantitatively using arbitrarily defined grades. Criteria for the diagnoses rely on empirical rules and are the result of consensus (Roufosse et al. 2018). All of these factors have led to insufficient inter-observer reproducibility for lesion scoring and diagnosis, potentially resulting in inappropriate treatment (Furness and Taub 2001, Mengel et al. 2007, Halloran et al. 2014, Broecker and Mengel 2015, Solez and Racusen 2013, Smith et al. 2019). The lack of independent validation is another recognised pitfall in the histological Banff classification (Mengel et al. 2007).

\section{Potential of molecular diagnostics}

Initially, RT-PCR evaluation of single transcripts or subsets of several transcripts associated with T-cell or cytokine burden were performed in small patient cohorts. Studies showed associations of acute rejection with higher mRNA expressions of several cytokines (Krams et al. 1992), Toll-like receptors (Dessing et al. 2010), as well as of chronic graft injury with profibrogenic cytokines and chemokines (Hribova et al. 2007), and of therapy-resistant rejection with Fas ligand gene expression (Nickel et al. 2001). Moreover, lower expression of regulatory transcript FOXP3 and $C D 20$ was shown to be associated with the inferior outcome of early acute rejection (Viklicky et al. 2010).

With the development of microarray technology, a large-scale analysis of transcriptomic data was carried out. Using microarray analysis in diagnostic and protocol kidney allograft biopsies, Sarwal et al. (2003) was the first who provided evidence of molecular heterogeneity of renal allograft rejection with respect to pathogenesis, clinical course, and response to treatment.

In parallel with microarray, the development of more quantitative and sensitive RNA-sequencing technologies has led to the evaluation of differential gene expression in a much broader dynamic range than microarrays. In their proof-of-concept discovery study, Kurian et al. (2017) compared Affymetrix Gene Arrays and RNA-Seq using transplant biopsies from patients with stable allograft and with acute rejection. Both platforms demonstrated equivalent predictive performance. Despite the promising potential of sequencing, the studies published thus far on the use of RNA-Seq for detecting differentially expressed genes in kidney allografts are scarce and limited to small sample sizes (Dziubianau et al. 2013, Jeon et al. 2017).

Transcriptomic profiling of kidney graft biopsies provided some new information in clinically unclear cases (Halloran, Reeve et al. 2017, Halloran, Famulski et al. 2017, Reeve et al. 2016) and revealed transcripts associated with disease progression (Kadota et al. 2015, Hruba et al. 2015, Lefaucheur et al. 2018). Compared to semi-quantitative histology assessment, transcriptomic results are not only quantitative but demonstrate higher specificity (Sis et al. 2009, Naesens et al. 2011, Reeve et al. 2016, Halloran et al. 2014). The other advantage of molecular assessment is the ability to adequately assess small tissue samples ( $3 \mathrm{~mm}$ in length) independently of proportion of cortex/medulla (Madill-Thomsen et al. 
Table 1. Molecular microscope body of evidence

\begin{tabular}{lll}
\hline Reference & $\begin{array}{l}\text { No. of } \\
\text { biopsies }\end{array}$ & \\
\hline Development of PBTs & Main findings \\
\hline $\begin{array}{l}\text { Mueller } \text { et al. } \\
2007\end{array}$ & $\begin{array}{l}\text { 143, } \\
\text { diagnostic }\end{array}$ & $\begin{array}{l}\text { PBTs representing three biological processes in graft rejection (cytotoxic T-cell infiltration } \\
\text { (QCAT), IFNG effects (GRIT1), and parenchymal deterioration (KT) increased in biopsies } \\
\text { with rejection (TCMR, ABMR, mixed) compared to non-rejection biopsies. }\end{array}$ \\
Sis et al. 2009 & $\begin{array}{l}\text { 173, } \\
\text { diagnostic }\end{array}$ & $\begin{array}{l}\text { Literature-based endothelium-associated transcripts (ENDATs, n=119) of which 25 were } \\
\text { differentially expressed between C4d+ABMR and TCMR (e.g. } \text { VWF, CAV1, RHOJ, MCAM, } \\
\text { CDH5, SELE). } \\
\text { DSAST: higher expression in DSA+ biopsies compared to DSA-. }\end{array}$ \\
Hidalgo et al. & $\begin{array}{l}\text { 145, } \\
\text { diagnostic }\end{array}$ &
\end{tabular}

\begin{tabular}{|c|c|c|}
\hline \multicolumn{3}{|c|}{ Development of classifiers } \\
\hline $\begin{array}{l}\text { Sellarés et al., } \\
2013\end{array}$ & $\begin{array}{l}403, \\
\text { diagnostic }\end{array}$ & $\begin{array}{l}\text { A molecular classifier for ABMR was built based on the top } 30 \text { differentially expressed } \\
\text { genes between ABMR and other biopsies (e.g. CDH13, CXCL11, DARC PLA1A, ROBO4, } \\
K L F 4, T M 4 S F 18, G N G 11 \text { ). }\end{array}$ \\
\hline $\begin{array}{l}\text { Reeve et al., } \\
2013\end{array}$ & $\begin{array}{l}403, \\
\text { diagnostic }\end{array}$ & $\begin{array}{l}\text { A molecular classifier for TCMR was built based on the top } 30 \text { differentially expressed } \\
\text { genes between TCMR and other biopsies (e.g. CD96, SIRPB2, TNFSF8, BTLA, OR2IIP, } \\
I L 21 R \text { ). }\end{array}$ \\
\hline $\begin{array}{l}\text { Famulski et al., } \\
2012\end{array}$ & $\begin{array}{l}\text { 39, protocol, } \\
\text { diagnostic }\end{array}$ & $\begin{array}{l}\text { A molecular classifier for AKI was built based on the top } 30 \text { differentially expressed genes } \\
\text { between pure AKI indication biopsies (n=28) and stable protocol biopsies ( } \mathrm{n}=11) \text {, including } \\
\text { ITGB6, SERPINA3, MTND6, OLFM4, PTX3, LCN2a,VCAN. }\end{array}$ \\
\hline $\begin{array}{l}\text { Einecke et al., } \\
2010\end{array}$ & $\begin{array}{l}105, \\
\text { diagnostic }\end{array}$ & $\begin{array}{l}\text { A molecular classifier for predicting graft loss was built based on the top } 30 \text { differentially } \\
\text { expressed transcripts between grafts failed within } 32 \text { months after for-cause biopsy and non- } \\
\text { failed grafts (e.g. ITGB6, HAVCR1, LTF, ADAMTS1, SERPINA3, NNMT, and VCAN). }\end{array}$ \\
\hline $\begin{array}{l}\text { Venner et al., } \\
2016\end{array}$ & $\begin{array}{l}681, \\
\text { diagnostic }\end{array}$ & $\begin{array}{l}\text { A molecular classifier for atrophy/fibrosis was built based on the top } 30 \text { differentially } \\
\text { expressed genes between early biopsies with no fibrosis (ci } \leq 1) \text { and late biopsies with fibrosis } \\
\text { (ci>1), including ITGB6, MIR } 21, V C A N, N N M T \text {, and } C P A 3 \text {. }\end{array}$ \\
\hline $\begin{array}{l}\text { Einecke et al., } \\
2018\end{array}$ & $\begin{array}{l}562, \\
\text { diagnostic }\end{array}$ & $\begin{array}{l}\text { A molecular classifier used to predict hyalinosis at a given time post-transplant was built } \\
\text { based on the top } 30 \text { differentially expressed genes between biopsies with ah }=0 \text { and ah>0 with } \\
\text { time correction, including } A P O B E C 3 G, H L A-G, B T N 3 A 1, C X C L 13, O R 2 I 1 P, P S M B 8 \text {, } \\
\text { ITGB6, MIR21,VCAN, NNMT, CPA3GCNT1,CD8B1, RAP2B, IL1ORB, and CNPY3. }\end{array}$ \\
\hline
\end{tabular}

\begin{tabular}{ll}
\hline \multicolumn{2}{l}{ Validation of MMDx } \\
\hline $\begin{array}{l}\text { Halloran } \text { et al., } \\
2013\end{array}$ & $\begin{array}{l}300, \\
\text { diagnostic }\end{array}$ \\
Halloran et al., & $\begin{array}{l}\text { 300, } \\
\text { diagnostic }\end{array}$
\end{tabular}
In the INTERCOM study ( 6 centres), TCMR scores correlated with histological TCMR lesions (tubulitis and interstitial inflammation). A TCMR score $>0.1$ predicted TCMR diagnosis with an accuracy of $87 \%$, similar to the reference set (89\%).
In the INTERCOM study (6 centres), molecular ABMR diagnosis was predicted by histology-based diagnosis in $59 \%$ of biopsies only. ABMR scores correlated with histological ABMR lesions and DSA. An ABMR score $>0.2$ predicted the diagnosis of ABMR or mixed rejection with an accuracy of $85 \%$ (identical to the reference set and local assessment).
Halloran et al., 538, In the INTERCOMEX study (10 centres), MMDx was verified in real-time. Agreement 2017 diagnostic between MMDx and histology was $77 \%$ for TCMR, $77 \%$ for ABMR, and $76 \%$ for no rejection. Despite MMDx and histology results differing in $24 \%$ of biopsy samples, clinicians disagreed more often with histology than with MMDX.

\section{MMDx as a tool to refine histological criteria}

\begin{tabular}{lll}
\hline $\begin{array}{l}\text { Halloran } \text { et al., } \\
2017\end{array}$ & $\begin{array}{l}703, \\
\text { diagnostic }\end{array}$ & $\begin{array}{l}\text { ABMR-positive MMDx scores correlated mainly with peritubular capillaritis, glomerulitis, } \\
\text { glomerular double contours, DSA, and C4d staining, but much less with arterial fibrosis and } \\
\text { vasculitis. }\end{array}$ \\
$\begin{array}{l}\text { Reeve } \text { et al., } \\
2016\end{array}$ & $\begin{array}{l}703, \\
\text { diagnostic }\end{array}$ & $\begin{array}{l}\text { TCMR-positive MMDx scores correlated mainly with interstitial infiltrate and tubulitis, but } \\
\text { less with arteritis (v-lesion). }\end{array}$ \\
$\begin{array}{l}\text { Halloran } \text { et al., } \\
2018\end{array}$ & $\begin{array}{l}238, \\
\text { diagnostic }\end{array}$ & $\begin{array}{l}\text { ABMR was diagnosed in } 45 \% \text { of i-IFTA biopsies with MMDx and in only } 28 \% \text { based on } \\
\text { histology. TCMR was diagnosed in } 16 \% \text { of i-IFTA biopsies with MMDx and in only } 8 \% \\
\text { based on histology. The prominent feature of i-IFTA biopsies was molecular injury (e.g. } \\
\text { acute kidney injury transcripts), which predicted graft loss. }\end{array}$ \\
\hline
\end{tabular}

PBTs: pathogenesis-based transcript sets, IFNG: interferon gamma, TCMR: T cell-mediated rejection, ABMR: antibody-mediated rejection, DSA: donor-specific antibody, DSAST: DSA-selective transcripts, AKI: acute kidney injury, MMDx: molecular microscope diagnostic system, i-IFTA: inflammation in areas of interstitial fibrosis-tubular atrophy 
2017), at least regarding molecular scores for ABMR, TCMR, and injury, but the impact of sample size on variability should be further explored (Halloran et al. 2017).

Microarray-derived molecular scores for ABMR and TCMR have been used to re-evaluate histological and serological criteria for rejection (Halloran, Famulski et al. 2017, Reeve et al. 2016). Molecular assessment of transcripts indicative of endothelial injury (Sis et al. 2010) in renal allografts was first added as a potential diagnostic criterion for ABMR to the Banff classification in 2013 (Haas et al. 2014). Findings on changes to endothelial transcripts, which can help to identify kidneys undergoing antibody-mediated injury, led to the inclusion of C4d-negative cases among ABMR categories (Sis et al. 2009). Transcriptomic data can therefore significantly improve diagnosis, prognosis, and prediction in kidney transplant settings.

Clearly, transcriptomic analyses cannot distinguish the source of gene transcripts when a part of the biopsy is stored in RNAlater which dissolve the tissue structure. Composition of the sample, e.g. the presence of glomeruli or the amount of fibrotic or inflamed tissue, also ultimately impacts on gene expression. Kidney compartment-specific expression can be satisfactorily assessed using laser-capture microdissection (Cohen et al. 2002, Serinsöz et al. 2005, Blakey and Laszik 2004, Tycova et al. 2018). However, tissue processing during laser microdissection requires careful handling to preserve RNA integrity. Obtaining a reasonable amount of microdissected compartments to isolate RNA of sufficient quantity represents also a great challenge. Tissue for microdissection can either be snap-frozen (Tycova et al. 2018) or fixed and then paraffin-embedded (Fries et al. 2003, Schmid et al. 2003, Bockmeyer et al. 2018). However, RNA yields are much higher from cryosections (Cohen at al. 2002). According to our study, RNA obtained from 10 microdissected 10 micrometrethick kidney glomeruli is sufficient for measuring around 10 transcripts by RT-qPCR (Tycova et al. 2018). Compartment-specific gene expression may help to identify the mechanisms involved in particular pathological processes (Seeger et al. 2018).

\section{Molecular microscope: past, present, and future}

Large-scale data generated by microarray require sophisticated statistical tools to extract biologically meaningful information. Based on the premise that transcript sets better reflect ongoing processes in kidney allograft than single transcripts, Halloran et al. introduced a definition for pathogenesis-based transcript sets (PBTs) (Table 1). The first graft pathology-related PBTs to be defined were based on experimental mouse kidney transplants (IFN- $\gamma$ and rejection-induced transcripts GRIT) (Famulski et al. 2006) and cell cultures (T- and B-cell-associated transcripts) (Hidalgo et al. 2012, Einecke et al. 2008). One study reported higher PBT scores in 143 consecutive human kidney transplant indication biopsies during rejection, notwithstanding similar ABMR and TCMR scores (Mueller et al. 2007). Sis et al. (2009) showed that expression of 119 endothelial-associated transcripts (selected based on the literature) was higher in ABMR than in TCMR, correlated with histopathological ABMR lesions, and predicted graft loss. Hidalgo et al. (2010) proposed a set of donor-specific antibody (DSA)selective transcripts (DSASTs). Further studies by the Halloran group significantly expanded the list of PBTs to reflect the major biological allograft processes (https://www.ualberta.ca/medicine/institutes-centresgroups/atagc/research/gene-lists). A comparison of 75 most ABMR-selective transcripts derived from the INTERCOMEX study with DSA-, endothelial cellassociated transcripts (ENDAT-), and C1q-binding antiHLA DSA-PBT sets showed that 17 transcripts were DSAselective $(22.6 \%), 14 \quad(18.7 \%)$ were endothelialassociated, and 2 transcripts (LST1 and FCGR3A) were complement-binding DSA-selective-associated (Fig. 1).

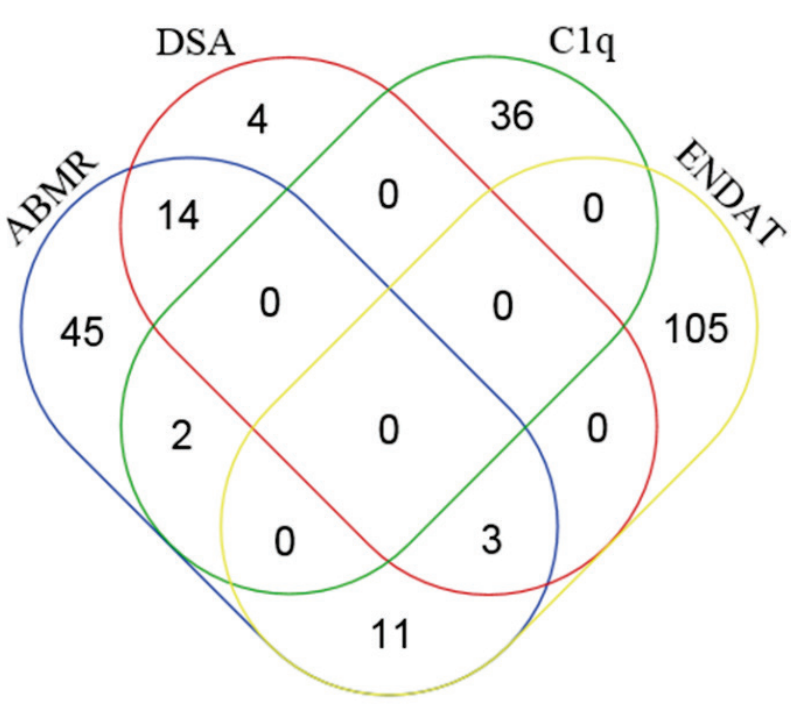

Fig. 1. The top 75 ABMR-selective transcripts derived from the INTERCOMEX study (Halloran, Reeve et al. 2017) were compared with particular PBTs using Venn diagrams. (http://bioinformatics.psb.ugent.be/webtools/Venn/). C1qbinding DSA PBT (Lefaucheur et al. 2018), DSA PBT (Hidalgo et al. 2010), ENDAT PBT (Sis et al. 2009). 
The advantage and validity of the PBT concept have been further confirmed by other groups. Using the same approach, Lubetzky et al. (2019) compared 49 patients with (transplant glomerulopathy) TG and microvascular inflammation to 51 patients with TG but no microvascular inflammation. Transplant glomerulopathy with microvascular inflammation had increased expression of IFN- $\gamma$ and rejection-induced transcripts and DSAST resembling ABMR, while TG biopsies without microvascular inflammation exhibited increased expression of cytotoxic and regulatory $\mathrm{T}$ cells and $\mathrm{B}$ cells, indicating TCMR.

Following PBTs, the Edmonton group developed several classifiers for particular kidney allograft pathologies, starting with ABMR and TCMR (Reeve et al. 2013, Sellares et al. 2013) (Table 1). Both classifiers were developed based on microarray profiling of 403 indication kidney graft biopsies. The TCMR classifier was built by comparing 35 histologically confirmed TCMR cases versus all other diagnoses, while the ABMR classifier was built by comparing both C4d-positive and C4d-negative ABMR ( $n=65)$ cases versus all other cases. Using linear discriminant analysis, the classifiers assigned an ABMR or TCMR score between 0 and 1.0 to each biopsy. The TCMR cut-off score $(>0.1)$ resulted in $50 \%$ sensitivity and $95 \%$ specificity for TCMR diagnosis. The top 30 genes selected by the classifier algorithm were either primarily expressed in effector $\mathrm{T}$ cells and myeloid cells or were IFN- $\gamma$-inducible. The ABMR cut-off score $(>0.2)$ resulted in $90 \%$ specificity and $67 \%$ sensitivity for ABMR diagnosis. The top 30 genes selected using the ABMR classifier algorithm were primarily endothelial, in addition to genes reflecting IFN- $\gamma$ effects, or presence of NK cells and myeloid cells.

The diagnostic performance of these newly developed molecular classifiers for ABMR and TCMR was validated by the prospective INTERCOM study, comprising six international centres (Halloran et al. 2013, Halloran et al. 2013) working with a central diagnostic system - the Molecular Microscope Diagnostic System ${ }^{\circledR}$ (MMDx) - at Alberta Transplant Applied Genomics Centre. MMDx compares gene expression data for a given biopsy to a reference set of samples, assigning probabilistic quantitative scores to diagnose rejection, acute parenchymal injury (Famulski et al. 2012), atrophy/fibrosis (Venner et al. 2016), and non-adherence (Einecke et al. 2018), or to predict progression to failure (Einecke et al. 2010, Loupy et al. 2014) (Table 1). For each biopsy, a summary of molecular changes, reference values, and interpretative analysis are provided. However, classifiers were developed and validated mainly in indication biopsies performed early or late after transplantation (Reeve et al. 2019) and its performance in protocol biopsies to reveal subclinical rejection still needs to be validated. The feasibility of MMDx as a real-time central molecular assessment system for kidney transplant biopsy samples was further evaluated by the prospective INTERCOMEX study, which analysed 519 biopsies from 10 centres in North America and Europe. Automated reports were generated based exclusively on MMDx classifier algorithms without knowledge of histologies or HLA antibodies (Halloran, Reeve et al. 2017). RNA quality and yield were almost uniformly high, $96 \%$ of biopsy samples were readable, and agreement between MMDx and histology exceeded $75 \%$. The authors concluded that real time central molecular assessment is feasible, the report satisfied clinicians' expectations more often than local histological assessment, and provided more weighted information for clinical decision-making.

MMDx overcomes several of the acknowledged limitations associated with microarray. The issue of insufficient reproducibility (Akalin and O'Connell 2010, Khatri et al. 2009, Halloran et al. 2014) was resolved using one microarray platform performed according to standard procedure at a single centre. Final scores were obtained using a large, fully phenotyped reference set in tandem with robust data analysis combining 12 different classifiers. Moreover, published data supported the notion that precision and accuracy of MMDx outperformed those of histology (Reeve et al. 2019).

Applying molecular ABMR scores permits the reassessment of histological and serological ABMR criteria (Table 1). Peritubular capillaritis, glomerulitis, glomerular double contours, DSA, and C4d staining are important features for ABMR diagnosis, whereas other Banff-recognised lesions demonstrate little (arteritis, arterial fibrous intimal thickening) or no (thrombotic microangiopathy, acute tubular injury, scarring) importance (Halloran, Famulski et al. 2017). Similarly, interstitial infiltrate and tubulitis are acknowledged as key histological predictors of molecular TCMR, with arteritis deemed less important (Reeve et al. 2016). In indication biopsies, i-IFTA is associated more with molecular injury and ABMR than with molecular TCMR (Halloran et al. 2018).

MMDx can complement histological criteria 
provided they fall under the threshold for rejection diagnosis, or prove discordant with immunopathological or serological criteria (Table 2). However, some limitations of MMDx have been exposed. Stereotyped changes in microarray may not be entirely diseasespecific. Given the small amount of tissue sampled, the heterogeneous cellular composition of the biopsy may theoretically impact on results (Akalin and O'Connell 2010). Focal changes (e.g. glomerular) tend to be evaluated less reliably than diffuse changes (Halloran et al. 2014, Halloran et al. 2015), while not all graft diseases might be evaluated accurately (e.g. glomerulonephritis, vascular and infectious pathology). It is unclear how inflammatory infiltrates in tubulointerstitial nephritis can be differentiated from acute rejection. Since MMDx is not a universal tool, nonrejection transplant pathology up to date can be better diagnosed with standard of care methods (e.g., light and fluorescent microscopy, and EM for glomerulonephritis,
IHC for polyoma large T antigen, EM for viral particles and plasma PCR screen for viral load in case of suspected polyoma BK nephropathy). However, MMDx can help to exclude rejection when it is mixed with other pathology of the graft. In addition to rejection scores MMDx comprises acute kidney injury, inflammation, atrophyfibrosis, and adherence scores that can help diagnose nonrejection transplant pathologies as well.

Prospective multicenter validation studies comparing MMDx-guided therapy with standard of care would help to strengthen the clinical significance of this new diagnostic tool and contribute to its routine adoption to clinical praxis. Moreover, in view of growing number of non-invasive molecular biomarkers for kidney graft evaluation (Suthanthiran et al. 2013, Roedder et al. 2014, Christakoudi et al. 2019, Huang et al. 2019) it will be interesting to compare diagnostic and prognostic performance of molecular microscope vs those molecular biomarkers.

Table 2. Examples of diagnostics pitfalls potentially resolved by using molecular methods

\begin{tabular}{|c|c|c|}
\hline Difficult diagnoses & Histology (Banff score) & Immunohistology + serology \\
\hline \multirow[t]{3}{*}{$\begin{array}{l}\text { Active } A B M R \text { vs. no } \\
\text { active } A B M R\end{array}$} & $\begin{array}{l}\text { MVI } \geq 1 \\
\text { ATI, in the absence of any other apparent cause, } \\
\text { MVI }<2 \\
\text { Acute TMA, in the absence of any other cause, } \\
\text { MVI }<2 \\
\text { V }>0, \text { MVI }<2\end{array}$ & C4d-negative, DSA-positive \\
\hline & $\begin{array}{ll} & \mathrm{MVI} \geq 2 \\
\cdot & \mathrm{V}>0, \mathrm{MVI}<2\end{array}$ & C4d-negative, DSA-negative \\
\hline & $\cdot \quad$ MVI 0 & C4d-positive, $\mathrm{DSA} \pm$ \\
\hline $\begin{array}{l}\text { Chronic active ABMR } \\
\text { vs. no chronic active } \\
\text { ABMR }\end{array}$ & $\begin{array}{ll}\cdot & \mathrm{cg}>0, \mathrm{MVI}<2 \\
\cdot & \text { Severe PTCBMML, MVI }<2 \\
\cdot & \text { AIF of new onset, excluding other causes, MVI }<2\end{array}$ & C4d-negative, DSA-positive \\
\hline $\begin{array}{l}\text { Acute } T C M R \text { vs. } \\
\text { no rejection }\end{array}$ & $\begin{array}{l}\mathrm{v}>0, \mathrm{MVI}<2, \mathrm{t} 0, \mathrm{i} 0 \\
\quad \mathrm{BL}, \text { i.e. under diagnostic threshold for rejection } \\
(\mathrm{t} \geq 2 \text { and } \mathrm{i} \geq 2)\end{array}$ & C4d-negative, DSA-negative \\
\hline $\begin{array}{l}\text { Pure TCMR I or BL vs. } \\
\text { mixed rejection }\end{array}$ & g 0, ptc $\geq 1$, acute TCMR I or BL & C4d-negative, DSA-positive \\
\hline $\begin{array}{l}\text { Pure TCMR II-III vs. } \\
\text { mixed rejection }\end{array}$ & $\mathrm{v}>0, \mathrm{MVI}<2$ & C4d-negative, $\mathrm{DSA} \pm$ \\
\hline $\begin{array}{l}\text { Isolated BKVN vs. } \\
\text { coincident with TCMR }\end{array}$ & t 2-3, i 2-3 & $\begin{array}{l}\text { C4d-negative, SV40-positive } \\
\text { DSA-negative }\end{array}$ \\
\hline
\end{tabular}

ABMR: antibody-mediated rejection, AIF: arterial intimal fibrosis, ATI: acute tubular injury, BL: borderline lesions, BKVN: BK virus nephropathy, DSA: donor-specific antibodies, MVI: microvascular inflammation ( $g+p t c)$ score, TCMR: T cell-mediated rejection, PTCBMML: peritubular capillary basement membrane multilayering, TMA: thrombotic microangiopathy, cg: glomerular basement membrane double contour score, v: arteritis score, t: tubulitis score, i: interstitial inflammation score, g: glomerulitis score, ptc: peritubular capillaritis score, SV40: simian virus antigen 40 . 


\section{Conclusions}

During past several decades, molecular assessment of kidney allograft has made striking progress, from evaluation of a single gene or their sets through PBTs and molecular classifiers to MMDx. High sensitivity and specificity of molecular scores have been used to improve histological and serological criteria for graft pathology. Integrating histological, serological, and molecular assessment of renal allografts may thus provide more accurate diagnostics to improve outcome of kidney transplantation.

\section{Conflict of Interest}

There is no conflict of interest.

\section{Acknowledgements}

This work was supported by the EU under ESIF, Operational Programme Research, development and education, CAMERA project (CZ.02.2.69/0.0/0.0/ 17 050/0008096) and by the Ministry of Health of the Czech Republic (MZO 00023001).

\section{References}

AKALIN E, O'CONNELL PJ: Genomics of chronic allograft injury. Kidney Int 78: S33-S37, 2010. https://doi.org/10.1038/ki.2010.420

BLAKEY GL, LASZIK ZG: Laser-assisted microdissection of the kidney: Fundamentals and applications. J Mol Histol 35: 581-587, 2004. https://doi.org/10.1007/s10735-004-2195-5

BOCKMEYER CL, WITTIG J, SÄUBERLICH K, SELHAUSEN P, EßER M, ZEUSCHNER P, MODDE F, AMANN K, DANIEL C: Recommendations for mRNA analysis of micro-dissected glomerular tufts from paraffinembedded human kidney biopsy samples. BMC Mol Biol 19: 2, 2018. https://doi.org/10.1186/s12867-0180103-X

BROECKER V, MENGEL M: The significance of histological diagnosis in renal allograft biopsies in 2014. Transplant Int 28: 136-145, 2015. https://doi.org/10.1111/tri.12446

CHRISTAKOUDI S, RUNGLALL M, MOBILLO P, TSUI T, DUFF C, DOMINGO-VILA C, KAMRA Y, DELANEY F, MONTERO R, SPIRIDOU A, KASSIMATIS T, PHIN-KON S, TUCKER B, FARMER C, STROM TB, LORD GM, REBOLLO-MESA I, STAHL D, SACKS S, HERNANDEZ-FUENTES MP, CHOWDHURY P: Development of a multivariable gene-expression signature targeting T-cell-mediated rejection in peripheral blood of kidney transplant recipients validated in cross-sectional and longitudinal samples. EBioMedicine 41: 571-583, 2019. https://doi.org/10.1016/j.ebiom.2019.01.060

COHEN CD, GRONE HJ, GRONE EF, NELSON PJ, SCHLONDORFF D, KRETZLER M: Laser microdissection and gene expression analysis on formaldehyde-fixed archival tissue. Kidney Int 61: 125-132, 2002. https://doi.org/10.1046/j.1523-1755.2002.00112.x

CORNELL LD: Rejection. In: Diagnostic Pathology: Kidney Diseases. RB COLVIN, A CHANG (eds.), Elsevier, Philadelphia, 2016, pp. 948-980.

DESSING MC, BEMELMAN FJ, CLAESSEN N, TEN BERGE IJ, FLORQUIN S, LEEMANS JC: Intragraft Toll-like receptor profiling in acute renal allograft rejection. Nephrol Dial Transplant 25: 4087-4092, 2010. https://doi.org/10.1093/ndt/gfq589

DZIUBIANAU M, HECHT J, KUCHENBECKER L, SATTLER A, STERVBO U, RODELSPERGER C, NICKEL P, NEUMANN AU, ROBINSON N, MUNDLOS S, VOLK HD, THIEL A, REINKE P, BABEL N: TCR repertoire analysis by next generation sequencing allows complex differential diagnosis of $\mathrm{T}$ cell-related pathology. Am J Transplant 13: 2842-2854, 2013. https://doi.org/10.1111/ajt.12431

EINECKE G, REEVE J, HALLORAN PF: A molecular biopsy test based on arteriolar under-hyalinosis reflects increased probability of rejection related to under-immunosuppression. Am J Transplant 18: 821-831, 2018. https://doi.org/10.1111/ajt.14532

EINECKE G, REEVE J, MENGEL M, SIS B, BUNNAG S, MUELLER TF, HALLORAN PF: Expression of B cell and immunoglobulin transcripts is a feature of inflammation in late allografts. Am J Transplant 8: 1434-1443, 2008. https://doi.org/10.1111/j.1600-6143.2008.02232.x 
EINECKE G, REEVE J, SIS B, MENGEL M, HIDALGO L, FAMULSKI KS, MATAS A, KASISKE B, KAPLAN B, HALLORAN PF: A molecular classifier for predicting future graft loss in late kidney transplant biopsies. J Clin Invest 120: 1862-1872, 2010. https://doi.org/10.1172/JCI41789

FAMULSKI KS, EINECKE G, REEVE J, RAMASSAR V, ALLANACH K, MUELLER T, HIDALGO LG, ZHU LF, HALLORAN PF: Changes in the transcriptome in allograft rejection: IFN-gamma-induced transcripts in mouse kidney allografts. Am J Transplant 6: 1342-1354, 2006. https://doi.org/10.1111/j.1600$\underline{6143.2006 .01337 . \mathrm{x}}$

FAMULSKI KS, DE FREITAS DG, KREEPAL CI, CHANG J, SELlARES J, SIS B, EINECKE G, MENGEL M, REEVE J, HALLORAN PH: Molecular phenotypes of acute kidney injury in kidney transplants. J Am Soc Nephrol 23: 948-958, 2012. https://doi.org/10.1681/ASN.2011090887

FRIES JW, ROTH T, DIENES HP, WEBER M, ODENTHAL M: A novel evaluation method for paraffinized human renal biopsies using quantitative analysis of microdissected glomeruli and VCAM-1 as marker of inflammatory mesangial cell activation. Nephrol Dial Transplant 18: 710-716, 2003. https://doi.org/10.1093/ndt/gfg045

FURNESS PN, TAUB N: International variation in the interpretation of renal transplant biopsies: report of the CERTPAP project. Kidney Int 60: 1998-2012, 2001. https://doi.org/10.1046/j.1523-1755.2001.00030.x

HAAS M, LOUPY A, LEFAUCHEUR C, ROUFOSSE C, GLOTZ D, SERON D, NANKIVELL BJ, HALLORAN PF, COLVIN RB, AKALIN E, ALACHKAR N., BAGNASCO S, BOUATOU Y, BECKER JU, CORNELL LD, DUONG VAN HUYEN JP, GIBSON IW, KRAUS ES, MANNON RB, NAESENS M, NICKELEIT V, NICKERSON P, SEGEV DL, SINGH HK, STEGALL M, RANDHAWA P, RACUSEN L, SOLEZ K, MENGEL M: The Banff 2017 kidney meeting report: revised diagnostic criteria for chronic active T cellmediated rejection, antibody-mediated rejection, and prospects for integrative endpoints for next-generation clinical trials. Am J Transplant 18: 293-307, 2018. https://doi.org/10.1111/ajt.14625

HAAS M, SIS B, RACUSEN LC, SOLEZ K, GLOTZ D, COLVIN RB, CASTRO MCR, DAVID DSR, DAVID-NETO E, BAGNASCO SM, CENDALES LC, CORNELL LD, DEMETRIS AJ, DRACHENBERG CB, FARVER CF, FARRIS AB, GIBSON IW, KRAUS E, LIAPIS H, LOUPY A, NICKELEIT V, RANDHAWA P, RODRIGUEZ ER, RUSH D, SMITH RN, TAN CD, WALLACE WD, MENGEL M: Banff 2013 meeting report: inclusion of C4d-negative antibody-mediated rejection and antibody-associated arterial lesions. Am J Transplant 14: 272-283, 2014. https://doi.org/10.1111/ajt.12590

HALLORAN PF, FAMULSKI K, REEVE J: The molecular phenotypes of rejection in kidney transplant biopsies. Curr Opin Organ Transplant 20: 359-367, 2015. https://doi.org/10.1097/MOT.0000000000000193

HALLORAN PF, FAMULSKI K, CHANG J: A probabilistic approach to histologic diagnosis of antibody-mediated rejection in kidney transplant biopsies. Am J Transplant 17: 129-139, 2017. https://doi.org/10.1111/ajt.13934

HALLORAN PF, PEREIRA AB, CHANG J, MATAS A, PICTON M, DE FREITAS D, BROMBERG J, SERON D, SELLARES J, EINECKE G, REEVE J: Potential impact of microarray diagnosis of T cell-mediated rejection in kidney transplants: the INTERCOM study. Am J Transplant 13: 2352-2363, 2013. https://doi.org/10.1111/ajt.12387

HALLORAN PF, PEREIRA AB, CHANG J, MATAS A, PICTON M, DE FREITAS D, BROMBERG J, SERON D, SELLARES J, EINECKE G, REEVE J: Microarray diagnosis of antibody-mediated rejection in kidney transplant biopsies: an international prospective study (INTERCOM). Am J Transplant 13: 2865-2874, 2013. https://doi.org/10.1111/ajt.12465

HALLORAN PF, REEVE JP, PEREIRA AB, HIDALGO LG, FAMULSKI KS: Antibody-mediated rejection, T cellmediated rejection, and the injury-repair response: new insights from the genome canada studies of kidney transplant biopsies. Kidney Int 85: 258-264, 2014. https://doi.org/10.1038/ki.2013.300

HALLORAN PF, REEVE J, AKALIN E, AUBERT O, BOHMIG GA, BRENNAN D, BROMBERG J, EINECKE G, ESKANDARY F, GOSSET C, DUONG VAN HUYEN J.-P, GUPTA G, LEFAUCHEUR C, MALONE A, MANNON RB, SERON D, SELLARES J, WEIR M, LOUPY A: Real time central assessment of kidney transplant indication biopsies by microarrays: The INTERCOMEX Study. Am J Transplant 17: 2851-2862, 2017. https://doi.org/10.1111/ajt.14329 
HALLORAN PF, MATAS A, KASISKE BL, MADILL-THOMSEN KS, MACKOVA M, FAMULSKI KS: Molecular phenotype of kidney transplant indication biopsies with inflammation in scarred areas. Am J Transplant 19:1356-1370, 2019. https://doi.org/10.1111/ajt.15178.

HIDALGO LG, SIS B, SELLARES J, CAMPBELL PM, MENGEL M, EINECKE G, CHANG J, HALLORAN PF: NK cell transcripts and NK cells in kidney biopsies from patients with donor-specific antibodies: evidence for NK cell involvement in antibody-mediated rejection. Am J Transplant 10: 1812-1822, 2010. https://doi.org/10.1111/j.1600-6143.2010.03201.x

HIDALGO LG, SELLARES J, SIS B, MENGEL M, CHANG J, HALLORAN PF: Interpreting NK cell transcripts versus $\mathrm{T}$ cell transcripts in renal transplant biopsies. Am J Transplant 12: 1180-1191. 2012. https://doi.org/10.1111/j.1600-6143.2011.03970.x

HRIBOVA P, LACHA J, KOTSCH K, VOLK HD, BRABCOVA I, SKIBOVA J, VITKO S, VIKLICKY O: Intrarenal cytokine and chemokine gene expression and kidney graft outcome. Kidney Blood Press Res 30: 273-282, 2007. https://doi.org/10.1159/000105134

HRUBÁ P, BRABCOVÁ I, GUELER F, KREJČÍK Z, STRÁNECKÝ V, SVOBODOVÁ E, MALUŠKOVÁ J, GWINNER W, HONSOVÁ E, LODEREROVÁ A, OBERBAUER R, ZACHOVAL R, VIKLICKÝ O: Molecular diagnostics identifies risks for graft dysfunction despite borderline histologic changes. Kidney Int 88: 785-795, 2015. https://doi.org/10.1038/ki.2015.211

HUANG E, SETHI S, PENG A, NAJJAR R, MIROCHA J, HAAS M, VO A, JORDAN SC: Early clinical experience using donor-derived cell-free DNA to detect rejection in kidney transplant recipients. Am J Transplant 19: 1663-1670, 2019. https://doi.org/10.1111/ajt.15289

JEON HJ, KIM K, LEE JG, JANG JY, CHOI S, FANG T, YAN JJ, HAN M, JEONG JC, LEE KB, KIM TJ, AHN C, YANG J: VDJ gene usage among B-cell receptors in ABO-incompatible kidney transplantation determined by RNA-seq transcriptomic analysis. BMC Nephrol 18: 340, 2017. https://doi.org/10.1186/s12882-017-0770-8

KADOTA PO, HAJJIRI Z, FINN PW, PERKINS DL: Precision subtypes of T cell-mediated rejection identified by molecular profiles. Front Immunol 6: 536, 2015. https://doi.org/10.3389/fimmu.2015.00536

KHATRI P, SARWAL MM: Using gene arrays in diagnosis of rejection. Curr Opin Organ Transplant 14: 34-39, 2009. https://doi.org/10.1097/MOT.0b013e32831e13d0

KRAMS SM, FALCO DA, VILLANUEVA JC, RABKIN J, TOMLANOVICH SJ, VINCENTI F, AMEND WJ, MELZER J, GAROVOY MR, ROBERTS JP: Cytokine and T cell receptor gene expression at the site of allograft rejection. Transplantation 53: 151-156, 1992. https://doi.org/10.1097/00007890-199201000-00031

KURIAN SM, VELAZQUEZ E, THOMPSON R, WHISENANT T, ROSE S, RILEY N, HARRISON F, GELBART T, FRIEDEWALD JJ, CHARRETTE J, BRIETIGAM S, PEYSAKHOVICH J, FIRST MR, ABECASSIS MM, SALOMON DR: Orthogonal comparison of molecular signatures of kidney transplants with subclinical and clinical acute rejection: Equivalent performance is agnostic to both technology and platform. Am J Transplant 17: 2103-2116, 2017. https://doi.org/10.1111/ajt.14224

LEFAUCHEUR C, VIGLIETTI D, HIDALGO LG, RATNER LE, BAGNASCO SM, BATAL I, AUBERT O, ORANDI BJ, OPPENHEIMER F, BESTARD O, RIGOTTI P, REISAETER AV, KAMAR N, LEBRANCHU Y, DUONG VAN HUYEN JP, BRUNEVAL P, GLOTZ D, LEGENDRE C, EMPANA JP, JOUVEN X, SEGEV DL, MONTGOMERY RA, ZEEVI A, HALLORAN PF, LOUPY A: Complement-activating antiHLA antibodies in kidney transplantation: allograft gene expression profiling and response to treatment. J Am Soc Nephrol 29: 620-635, 2018. https://doi.org/10.1681/ASN.2017050589

LOUPY A, HAAS M, SOLEZ K, RACUSEN L, GLOTZ D, SERON D, NANKIVELL BJ, COLVIN RB, AFROUZIAN M, AKALIN E, ALACHKAR N, BAGNASCO S, BECKER JU, CORNELL L, DRACHENBERG C, DRAGUN D, DE KORT H, GIBSON IW, KRAUS ES, LEFAUCHEUR C, LEGENDRE C, LIAPIS H, MUTHUKUMAR T, NICKELEIT V, ORANDI B, PARK W, RABANT M, RANDHAWA P, REED EF, ROUFOSSE C, SESHAN SV, SIS B, SINGH HK, SCHINSTOCK C, TAMBUR A, ZEEVI A, MENGEL M: The Banff 2015 kidney meeting report: current challenges in rejection classification and prospects for adopting molecular pathology. Am J Transplant 17: 28-41, 2017. https://doi.org/10.1111/ajt.14107 
LOUPY A, LEFAUCHEUR C, VERNEREY D, CHANG J, HIDALGO LG, BEUSCART T, VERINE J, AUBERT O, DUBLEUMORTIER S, DUONG VAN HUYEN JP, JOUVEN X, GLOTZ D, LEGENDRE C, HALLORAN PF: Molecular microscope strategy to improve risk stratification in early antibody-mediated kidney allograft rejection. J Am Soc Nephrol 25: 2267-2277, 2014. https://doi.org/10.1681/ASN.2013111149

LUBETZKY M, HAYDE N, Ó BROIN P, AJAIMY M, BAO Y, MOHAMMED O, SCHWARTZ D, PULLMAN J, AKALIN E: Molecular signatures and clinical outcomes of transplant glomerulopathy stratified by microvascular inflammation and donor-specific antibody. Clin Transplant 33: e13469, 2019. https://doi.org/10.1111/ctr.13469

MADILL-THOMSEN KS, WIGGINS RC, ESKANDARY F, BÖHMIG GA, HALLORAN PF: The effect of cortex/medulla proportions on molecular diagnoses in kidney transplant biopsies: rejection and injury can be assessed in medulla. Am J Transplant 17: 2117-2128, 2017. https://doi.org/10.1111/ajt.14233

MENGEL M, CHAN S, CLIMENHAGA J, KUSHNER YB, REGELE H, COLVIN RB, RANDHAWA P: Banff initiative for quality assurance in transplantation (BIFQUIT): Reproducibility of C4d immunohistochemistry in kidney allografts. Am J Transplant 13: 1235-1245, 2013. https://doi.org/10.1111/ajt.12193

MENGEL M, SIS B, HALLORAN PF: SWOT analysis of Banff: Strengths, weaknesses, opportunities and threats of the international Banff consensus process and classification system for renal allograft pathology. Am J Transplant 7: 2221-2226, 2007. https://doi.org/10.1111/j.1600-6143.2007.01924.x

MUELLER TF, EINECKE G, REEVE J, SIS B, MENGEL M, JHANGRI GS, BUNNAG S, CRUZB J, WISHART D, MENG C, BRODERICK G, KAPLAN B, HALLORAN PF: Microarray analysis of rejection in human kidney transplants using pathogenesis-based transcript sets. Am J Transplant 7: 2712-2722, 2007. https://doi.org/10.1111/j.1600-6143.2007.02005.x

NAESENS M, KHATRI P, LI L, SIGDEL TK, VITALONE MJ, CHEN R, BUTTE AJ, SALVATIERRA O, SARWAL MM: Progressive histological damage in renal allografts is associated with expression of innate and adaptive immunity genes. Kidney Int 80: 1364-1376, 2011. https://doi.org/10.1038/ki.2011.245

NICKEL P, LACHA J, ODE-HAKIM S, SAWITZKI B, BABEL N, FREI U, VOLK HD, REINKE P: Cytotoxic effector molecule gene expression in acute renal allograft rejection: correlation with clinical outcome; histopathology and function of the allograft. Transplantation 72: 1158-1160, 2001. https://doi.org/10.1097/00007890-200109270-00031

RACUSEN LC, SOLEZ K, COLVIN RB, BONSIB SM, CASTRO MC, CAVALLO T, CROKER BP, DEMETRIS AJ, DRACHENBERG CB, FOGO AB, FURNESS P, GABER LW, GIBSON IW, GLOTZ D, GOLDBERG JC, GRANDE J, HALLORAN PF, HANSEN HE, HARTLEY B, HAYRY PJ, HILL CM, HOFFMAN EO, HUNSICKER LG, LINDBLAD AS, YAMAGUCHI Y: The Banff 97 working classification of renal allograft pathology. Kidney Int 55: 713-723, 1999. https://doi.org/10.1046/j.1523-1755.1999.00299.x

REEVE J, BÖHMIG GA, ESKANDARY F, EINECKE G, GUPTA G, MADILL-THOMSEN K, MACKOVA M, | HALLORAN PH: Generating automated kidney transplant biopsy reports combining molecular measurements with ensembles of machine learning classifiers. Am J Transplant 19: 2719-2731, 2019. https://doi.org/10.1111/ajt.15351

REEVE J, CHANG J, SALAZAR IDR, LOPEZ MM, HALLORAN PF: Using molecular phenotyping to guide improvements in the histologic diagnosis of T cell-mediated rejection. Am J Transplant 16: 1183-1192, 2016. https://doi.org/10.1111/ajt.13572

REEVE J, SELlARES J, MENGEL M, SIS B, SKENE A, HIDALGOA L, DE FREITASD DG, FAMULSKI KS, HALLORAN PF: Molecular diagnosis of T cell-mediated rejection in human kidney transplant biopsies. Am J Transplant 13: 645-655, 2013. https://doi.org/10.1111/ajt.12079

ROEDDER S, SIGDEL T, SALOMONIS N, HSIEH S, DAI H, BESTARD O, METES D, ZEEVI A, GRITSCH A, CHEESEMAN J, MACEDO C, PEDDY R, MEDEIROS M, VINCENTI F, ASHER N, SALVATIERRA O, SHAPIRO R, KIRK A, REED EF, SARWAL MM: The kSORT assay to detect renal transplant patients at high risk for acute rejection: results of the multicenter AART study. PLoS Med. 11: e1001759, 2014. https://doi.org/10.1371/journal.pmed.1001759 
ROUFOSSE C, SIMMONDS N, CLAHSEN-VAN GRONINGEN M, HAAS M, HENRIKSEN KJ, HORSFIELD C, LOUPY A, MENGEL M, PERKOWSKA-PTASIŃSKA A, RABANT M, RACUSEN LC, SOLEZ K, BECKER JU: A 2018 reference guide to the Banff classification of renal allograft pathology. Transplantation 102: 1795-1814, 2018. https://doi.org/10.1097/TP.0000000000002366

SÁ H, LEAL R, SANTOS ROSA M: Renal transplant immunology in the last 20 years: A revolution towards graft and patient survival improvement. Int Rev Immunol 36: 182-203, 2017. https://doi.org/10.1080/08830185.2016.1225300

SARWAL M, CHUA MS, KAMBHAM N, HSIEH SC, SATTERWHITE T, MASEK M, SALVATIERRA O JR: Molecular heterogeneity in acute renal allograft rejection identified by DNA microarray profiling. N Engl J Med 349: 125-138, 2003. https://doi.org/10.1056/NEJMoa035588

SCHMID H, HENGER A, COHEN CD, FRACH K, GRONE H-J, SCHLONDORFF D, KRETZLER M: Gene expression profiles of podocyte-associated molecules as diagnostic markers in acquired proteinuric diseases. J Am Soc Nephrol 14: 2958-2966, 2003. https://doi.org/10.1097/01.ASN.0000090745.85482.06

SEEGER H, LINDENMEYER MT, COHEN CD, JAECKEL C, NELSON PJ, CHEN J, EDENHOFER I, KOZAKOWSKI N, REGELE H, BOEHMIG G, BRANDT S, WUETHRICH RP, HEIKENWALDER M, FEHR T, SEGERER S: Lymphotoxin expression in human and murine renal allografts. PLoS ONE 13: e0189396, 2018. https://doi.org/10.1371/journal.pone.0189396

SELLARÉS J, DE FREITAS DG, MENGEL M, REEVE J, EINECKE G, SIS B, HIDALGO LG, FAMULSKI K, MATAS A, HALLORAN PF: Understanding the causes of kidney transplant failure: The dominant role of antibody-mediated rejection and nonadherence. Am J Transplant 12: 388-399, 2012. https://doi.org/10.1111/j.1600-6143.2011.03840.x

SELLARES J, REEVE J, LOUPY A, MENGEL M, SIS B, SKENE A, DE FREITAS D, KREEPALA C, HIDALGO LG, FAMULSKI KS, HALLORAN PF: Molecular diagnosis of antibody-mediated rejection in human kidney transplants. Am J Transplant 13: 971-983, 2013. https://doi.org/10.1111/ajt.12150

SERINSOZ E, BOCK O, GWINNER W, SCHWARZ A, HALLER H, KREIPE H, MENGEL M: Local complement C3 Expression is upregulated in humoral and cellular rejection of renal allografts. Am $\mathrm{J}$ Transplant 5: 1490-1494, 2005. https://doi.org/10.1111/j.1600-6143.2005.00873.x

SIS B, MENGEL M, HAAS M, COLVIN RB, HALLORAN PF, RACUSEN LC, SOLEZ K, BALDWIN III WM, BRACAMONTE ER, BROECKER V, COSIO F, DEMETRIS AJ, DRACHENBERG C, EINECKE G, GLOOR J, GLOTZ D, KRAUS E, LEGENDRE C, LIAPIS H, MANNON RB, NANKIVELL BJ, NICKELEIT V, PAPADIMITRIOU JC, RANDHAWA P, REGELE H, RENAUDIN K, RODRIGUEZ ER, SERON D, SESHAN S, SUTHANTHIRAN M, WASOWSKA BA, ZACHARY A, ZEEVI A: Banff '09 meeting report: antibody mediated graft deterioration and implementation of Banff working groups. Am $\mathrm{J}$ Transplant 10: 464-471, 2010. https://doi.org/10.1111/j.1600-6143.2009.02987.x

SIS B, JHANGRI GS, BUNNAG S, ALLANACH K, KAPLAN B, HALLORAN PF: Endothelial gene expression in kidney transplants with alloantibody indicates antibody-mediated damage despite lack of C4d staining. Am J Transplant 9: 2312-2323, 2009. https://doi.org/10.1111/j.1600-6143.2009.02761.x

SMITH B, CORNELL LD, SMITH M, CORTESE C, GEIGER X, ALEXANDER MP RYAN M, PARK W, MORALES ALVAREZ MC, SCHINSTOCK C, KREMERS W, STEGALL M: A method to reduce variability in scoring antibody-mediated rejection in renal allografts: implications for clinical trials - a retrospective study. Transpl Int 32: 173-183, 2019. https://doi.org/10.1111/tri.13340

SOLEZ K, AXELSEN RA, BENEDIKTSSON H, BURDICK JF, COHEN AH, COLVIN RB, CROKER BP, DROZ D, DUNNILL MS, HALLORAN PF, HAYRY P, JENNETTE JC, KEOWN PA, MARCUSSEN N, MIHATSCH MJ, Morozumi K, MYERS BD, NAST CC, OLSEN S, RACUSEN LC, RAMOS EL, ROSEN S, SACHS DH, SALOMON DR, SANFILIPPO F, VERANI R, VON WILLEBRAND E, YAMAGUCHI Y: International standardization of criteria for the histologic diagnosis of renal allograft rejection: the Banff working classification of kidney transplant pathology. Kidney Int 44: 411-422, 1993. https://doi.org/10.1038/ki.1993.259

SOLEZ K, RACUSEN LC: The Banff classification revisited. Kidney Int. 83: 201-206, 2013. https://doi.org/10.1038/ki.2012.395 
SUTHANTHIRAN M, SCHWARTZ JE, DING R, ABECASSIS M, DADHANIA D, SAMSTEIN B, KNECHTLE SJ, FRIEDEWALD J, BECKER YT, SHARMA V, WILLIAMS NM, CHANG CS, HOANG C, MUTHUKUMAR T, AUGUST P, KESLAR KS, FAIRCHILD RL, HRICIK DE, HEEGER PS, HAN L, LIU J, RIGGS M, IKLE DN, BRIDGES ND, SHAKED A: Urinary-cell mRNA profile and acute cellular rejection in kidney allografts. N Engl J Med 369: 20-31, 2013. https://doi.org/10.1056/NEJMoa1215555

TYCOVÁ I, HRUBÁ P, MAIXNEROVÁ D, GIRMANOVÁ E, MRÁZOVÁ P, STRAŇAVOVÁ L, ZACHOVAL R, MERTA M, SLATINSKÁ J, KOLLÁR M, HONSOVÁ E, TESAŘ V, VIKLICKÝ O: Molecular profiling in IgA nephropathy and focal and segmental glomerulosclerosis. Physiol Res 67: 93-105, 2018. https://doi.org/10.33549/physiolres.933670

VENNER JM, FAMULSKI KS, REEVE J, CHANG J, HALLORAN PF: Relationships among injury, fibrosis, and time in human kidney transplants. JCI Insight 1: e85323, 2016. https://doi.org/10.1172/jci.insight.85323

VIKLICKY O, HRIBOVA P, VOLK HD, SLATINSKA J, PETRASEK J, BANDUR S, HONSOVA E, REINKE P: Molecular phenotypes of acute rejection predict kidney graft prognosis. J Am Soc Nephrol 21: 173-180, 2010. https://doi.org/10.1681/ASN.2008121268 